\title{
CRITICAL THINKING OF IT TEACHERS AS IMPORTANT COMPONENT OF THEIR PROFESSIONAL COMPETENCE
}

\author{
Vita Ovdiichuk \\ Postgraduate Student, Academician Stepan Demianchuk International University \\ of Economics and Humanities, Ukraine \\ e-mail: vika.gandzyuk@gmail.com,orcid.org/0000-0002-3818-1383
}

\section{Summary}

The article analyzes the role of critical thinking in professional growth, proves that critical thinking is an integral part of the professional competencies of future computer science teachers, an important component of modern higher education. The definition of the concept of critical thinking is clarified and presented in the author's interpretation as a type of thinking and evaluation activity, which is manifested in special skills that are formed in the process of professional training, and which are necessary for the effective solution of professional problems. The study outlines the principles of development of critical thinking and identifies four stages of development of critical thinking of future computer science teachers. The author of the article emphasizes the observance of certain pedagogical conditions in the process of forming students' critical thinking: taking into account age, level of educational achievements, available life experience. It was found that the basis of critical thinking is such qualities of the mind as curiosity, flexibility, depth, discipline, organization of mental activity, critical thinking, which must be developed in the future specialist. Based on the analysis of scientific sources and practical developments, it is proved that critical thinking is the key to the productive professional activity of future teachers in ensuring compliance with the requirements for mandatory learning outcomes of students in the field of informatics, self-improvement, reflection.

Keywords: critical thinking, development of critical thinking, competence, future teachers of computer science, the institution of higher education.

DOI: https://doi.org/10.23856/4511

\section{Introduction}

In the system of continuing education, which is formed in the conditions of rapid renewal of equipment and technologies, socio-economic changes, one of the key tasks is "development of future-oriented thinking", because in today's information society the knowledge that needs to be understood is important. (National Strategy, 2013). The current professional market requires the ability to apply them in practice quickly, efficiently and creatively in solving various problems that arise in work and everyday life.

For several years in a row, critical, analytical thinking, digital information analysis skills remain in the ranking of top skills that modern specialists must have in order to be in demand in the labor market; ability to solve problems comprehensively; creativity and originality; leadership and organizational skills; application of new technologies for professional growth, self-improvement and development; resilience, stress resistance, flexibility (The Future of Jobs Report, 2020).

Therefore, one of the priority tasks of Ukrainian higher education is the training of competent specialists, in particular, computer science teachers who have such skills and abilities, including critical thinking (CT). 
The purpose of the article is to analyze the role of critical thinking in the professional growth of future teachers, to clarify the concepts, stages of development of critical thinking, to justify the importance of its development for the formation of professional competencies.

\section{Analysis of the researches and publications}

The founders of critical thinking are E. de Bono, W. James, J. Dewey, D. Cluster, M. Lipman, K. Meredith, R. Paul, C. Temple, P. Freire, D. Halpern and others, who studied this problem. The development of critical thinking of student youth and future teachers attracted the attention of A. Avershyn, A. Bublyk, L. Kienko-Romanyuk, K. Krasnolutsky, Y. Lishchuk, I. Mushtavinska, M. Pochynkova, A. Solomenko, O. Tyaglo, T. Kharlampyeva, T. Khachumyan, T. Yakovenko and others. Scientists offer methods of CT development with the use of project technology, interactive methods and techniques, business games, substantiate ways of forming CT by means of information technologies, etc. At the same time, the problem of the developing critical thinking of future computer science teachers remains insufficiently studied.

\section{Presenting of basic material}

Professional and personal qualities, values, ways of thinking of a computer science teacher are a constant topic for discussion. After all, today computer science teachers act not only as teachers but also perform the functions of mentors, consultants to subject teachers on the use and implementation of digital technologies in the educational process, ensure the functioning of information management systems of educational institutions.

Different concepts and approaches are used to ensure high-quality training of future teachers in higher education institutions, but according to scientists, the competence approach is the starting point for reforming national education (National Report, 2016).

"Competence approach involves the training of a specialist as a process of formation of competencies that allows you to implement professional functions and competencies that ensure the implementation of certain professional activities" (Gusak et al., 2015: 10).

The works of N. Balyk, V. Bykov, M. Zhaldak, N. Morse, S. Rakov, S. Semerikov, O. Spirin, Y. Ramsjkyj, Y. Trius are devoted to the problem of formation of professional, general competencies in the process of professional training of future teachers of computer science, etc. There are also dissertation researches by O. Mojko, O. Krivonos, A. Kirilov and others.

In a joint study, M. Zhaldak, Y. Ramsjkyj and M. Rafaljsjka note that "the formation of professional competencies of computer science teachers involves the acquisition of competencies in computer science and related disciplines, teaching methods and didactics, psychological and pedagogical foundations of the educational process, research and pedagogical communication, which determines the quality of his professional activity" (Zhaldak et al., 2009: 6).

Mastering competence requires significant intellectual development, abstract thinking, self-reflection, self-esteem, self-determination, critical thinking (Selevko, 2006).

At one time, exploring the concept of competence, its components, J. Raven identified the types of competencies (motivated abilities) that are necessary for specialist to successfully achieve their goals. This list also includes critical thinking (Raven, 2002).

Scientists define thinking as an important component of the formation of professionalism, the development of intellectual and creative abilities of the future specialist, the development of professional competencies (Kokun, 2012, Morse et al., 2010). 
In the dissertation research M. Zhaldak, based on the work of Biryukov B.V, Petrov Y.A, Sohor A.M and others, emphasized the importance of logical training of teachers of computer science, the development of informal, creative components of thinking: problem statement or creation problem situation; formulation of criteria in the selection of the necessary operations for the solution; making hypotheses, assumptions in the search for solutions that require a creative approach, rather than reduced to combinatorics and the generation of random states; material representation of the formal solution; understanding, etc. (Zhaldak, 1989).

The formation and development of competence are determined by the variation of approaches, strategies aimed at solving professional problems, and critical control of their application. Critical thinking is closely linked to the success of such tasks due to the metacognitive strategies that are part of it (Kukushkina, 2008). In particular, one of the important metacognitive abilities is the ability of a person to self-regulate their own educational and cognitive activities (self-education):

- the ability to evaluate what she knows and what she does not yet know;

- ability to set a task;

- ability to build an algorithm for its solution;

- ability to organize the search for its solution;

- ability to evaluate the obtained results and comprehend one's own activity in finding a solution to the problem. Metacognitive abilities also include the open cognitive position of the individual (Kuljutkin, 2002). It is thanks to such skills that students will be able to consciously learn, gain experience, apply it in new conditions to solve professional problems.

Understanding competence as the ability to act in a situation of uncertainty, scientists call critical thinking and cognitive flexibility basic competencies on the basis of which other competencies are formed and developed (Zhukockaja et al., 2019).

The professional standard for the professions "Primary school teacher of general secondary education", "Teacher of general secondary education", "Primary education teacher (with a diploma of a junior specialist)" defines the list of general (civic, social, culture of expression, leadership, entrepreneurship )and professional competencies (language-communicative, subject-methodical, information-digital psychological, emotional-ethical, competence of pedagogical partnership, inclusive, health-preserving, design, prognostic, organizational, assessment-analytical, innovative, ability to learn during life, reflexive), which must have a modern teacher to successfully perform labor functions. These competencies include the ability to: work critically with information; operate with information in professional activities; critically evaluate information, strategies, ICT, digital technologies to work with it; to form students' ability to social interaction; create conditions for positive self-esteem of students; ability to make rational decisions based on facts; use the practice of critical thinking in the educational process; awareness and understanding of other people's emotions; monitor own requests and needs; self-reflect; evaluate the effectiveness of their own teaching activities and others (Professional Standard, 2020). These skills are within the competence of critical thinking. Therefore, CT is one of the most important cross-cutting skills, the basis for the formation and development of computer science teacher competencies, a guarantee that the teacher will be able to develop this type of thinking in students and teach critical thinking, because "... teacher educates primarily his thoughts, his thinking. And pedagogical activity is, first of all, the work of thought, aimed at inspiring pupils with the desire to know, to think, to have the right views of the world around them " (Sukhomlynsjkyj, 1976: 198).

Critical thinking should be developed, starting with preschool education, continue to develop in general and higher education, improve during the performance of professional 
activities, solving life problems. In particular, in general secondary and higher education institutions, this can be done by introducing a separate discipline "Critical Thinking". The teaching of CT at different levels of education should be continuous, coordinated. Through the use of critical thinking in the teaching of other courses will help increase the level of mastery of disciplines that use its resources (Bondar, 2014, Tjaghlo, 2017).

The development of thinking skills does not happen spontaneously. To improve them, students must make a systematic effort and consciously focus on improving them. If this is not done during the educational process, then students develop inertia, stereotyped thinking and activities, which are then transferred to the professional sphere (Zhukockaja et al., 2019).

The main goal of forming students' critical thinking if they do not have stable skills to think critically is to expand thinking competencies for effective solutions of social, scientific and practical problems (Shakirova, 2006).

The teacher directs efforts to the following aspects of students' thinking: 1) development of all types and forms of thinking and facilitating the transition from one to another; 2) formation and improvement of mental operations; 3) the development of skills to distinguish significant properties of objects from insignificant, to find connections and relationships of things and phenomena in the environment; to make correct conclusions on the basis of facts, to check their reliability; to prove the truth of one's own judgments and refute erroneous inferences, to express one's opinions consistently, to argue them; 4) the formation of skills to transfer operations and techniques from one field of knowledge to another; predict the development of phenomena and draw sound conclusions; 5) stimulating the process of transition from thinking based on formal logic to thinking based on dialectical logic; improving the ability to use the laws of logic in educational and cognitive activities (Vitvycjka, 2014). Such tasks should take into account age, level of academic achievement, existing life experience of higher education students (Shakirova, 2006).

In order for students to think critically, they also need to develop: intellectual humility (understanding the limits of knowledge, attention to distortion, inaccuracies, limited vision); intellectual courage (willingness to meet and fairly assess other points of view, regardless of their own attitude to them); intellectual compassion recognition of the need to present oneself in the place of others in order to sincerely understand another's position); intellectual honest intentions (directness, recognition of the need to be truthful in one's own judgment in order to be consistent in intellectual standards; when selecting facts and evidence, adhere to strict standards, as we require others to act contrary to them); intellectual persistence (willingness to go to an intellectual goal, despite the difficulties); belief in the cause (belief that if people will formulate their own conclusions, developing their rational abilities, then, in the end, the higher interests and the interests of humanity as a whole will be served as best as possible); intellectual semantic justice (willingness to accept different points of view with understanding and evaluate them objectively) (Paul, 1990).

Critical thinking of the future teacher includes assessment and reflection of the mental process, mental and practical activities. These components are due to the properties of thinking (flexibility, pace of development of mental processes; depth, breadth, independence; consistency of thought, criticality), intellectual and personal qualities of the teacher (openness to the new, critical mind, divergent thinking) convergence, lability, stereotypes, impulsiveness, reflexivity of thinking) and are realized on the basis of the categorical apparatus of thinking of the teacher, which provides a sequence of logical inferences, making rational, informed decisions, helps to solve problematic pedagogical situations. The basis of critical thinking, which should be developed in the future specialist, are such qualities of mind as curiosity, flexibility, depth, discipline, organization of mental activity, critical thinking (Semenova, 2018). 
The critical thinking of a future computer science teacher is understood as a type of thinking and evaluation activity, which is manifested in special skills necessary for effective professional tasks, and are formed in the process of the professional training during the study of computer science disciplines (Ludova, 2009).

The main principles that ensure the process of the developing students' critical thinking are: 1) identifying and refuting assumptions; 2) verification of actual accuracy and logical sequence; 3 ) consideration of the context; 4) study of alternatives; 5) use of available pedagogical potential; 6) axiological principle; 7) emotional intelligence (Barbinova, 2018).

In the psychological and pedagogical literature, there are attempts to distinguish the stages of the development of critical thinking by M. Veksler, T. Kyjenko-Romanjuk, O. Tjaghlo, M. Shakirova, S. Zair-Bek, I. Mushtavinsjka and others. (Tjaghlo, 2008, Shakirova, 2006, ZayrBek et al., 2011). Let's consider the stages (phases) of development of CT given by scientists in the table on which employment in the course of training is built (see Table 1).

Table 1

Developing stages of critical thinking

\begin{tabular}{|c|c|c|c|}
\hline $\begin{array}{c}\text { Stages / } \\
\text { phases }\end{array}$ & M. Shakirova & O. Tjaghlo & $\begin{array}{l}\text { S. Zair-Bek, } \\
\text { I. Mushtavinsjka }\end{array}$ \\
\hline I & $\begin{array}{l}\text { The first stage. Actualiza- } \\
\text { tion of knowledge, awaken- } \\
\text { ing of interest in the studied } \\
\text { material, definition of the } \\
\text { purposes of mastering of } \\
\text { the information. }\end{array}$ & $\begin{array}{l}\text { Analysis phase. } \\
\text { Analysis of the problem } \\
\text { and the proposed solution. } \\
\text { Consideration of grounds } \\
\text { and arguments }\end{array}$ & $\begin{array}{l}\text { Evocation (call phase, } \\
\text { awakening). } \\
\text { Actualization of knowl- } \\
\text { edge, awakening of interest } \\
\text { in the studied material in } \\
\text { the student, motivation for } \\
\text { further work. }\end{array}$ \\
\hline II & $\begin{array}{l}\text { The second stage. } \\
\text { Comprehension of new } \\
\text { information, critical reading } \\
\text { and writing. }\end{array}$ & $\begin{array}{l}\text { Understanding phase. } \\
\text { Clarification of incompre- } \\
\text { hensible concepts or judg- } \\
\text { ments, the essence of value } \\
\text { and descriptive assumptions. } \\
\text { Consideration of condi- } \\
\text { tions that allow to accept } \\
\text { arguments. }\end{array}$ & $\begin{array}{l}\text { Realization (phase of com- } \\
\text { prehension of new infor- } \\
\text { mation). } \\
\text { Comprehension of new } \\
\text { information, meaningful } \\
\text { reading, writing, direct } \\
\text { work with information. }\end{array}$ \\
\hline III & $\begin{array}{l}\text { The third stage. } \\
\text { Reasoning or reflection, the } \\
\text { formation of personal opin- } \\
\text { ion, attitude to information. } \\
\text { The fourth stage. } \\
\text { Generalization and eval- } \\
\text { uation of information, } \\
\text { problems, ways to solve it, } \\
\text { own capabilities. }\end{array}$ & $\begin{array}{l}\text { Evaluation phase. } \\
\text { Assessment of the prob- } \\
\text { lem and correctness of } \\
\text { conclusions, solutions. } \\
\text { Evaluation of reasons, logic } \\
\text { of constructed inferences, } \\
\text { argumentation. Reflection } \\
\text { (reflection phase). } \\
\text { Information analysis, inter- } \\
\text { pretation, reflection }\end{array}$ & $\begin{array}{l}\text { Reflection (reflection phase). } \\
\text { Information analysis, inter- } \\
\text { pretation, reflection }\end{array}$ \\
\hline IV & $\begin{array}{l}\text { The fourth stage. } \\
\text { Generalization and eval- } \\
\text { uation of information, } \\
\text { problems, ways to solve it, } \\
\text { own capabilities. }\end{array}$ & $\begin{array}{l}\text { Criticism phase. } \\
\text { Review the solution of the } \\
\text { problem, check for errors, } \\
\text { find ways to eliminate } \\
\text { them, strengthen reasoning. }\end{array}$ & \\
\hline
\end{tabular}


Described by S. Zair-Bek, I. Mushtavinsjka technological phases of the development of critical thinking correspond to the model "Technologies of development of critical thinking through reading and writing", developed by American researchers Ch.Temple, K. Meredith, J. Steele, etc., which has recently acquired popularity in pedagogical practice (Crawford et al., 2006). Each phase of the technology of the development of critical thinking is characterized by the use of certain methods and techniques of working with information. The application of techniques and adherence to the technological structure of the educational process is focused on the development of the subjective position of students, achieving a high level of critical thinking.

The stages (phases) of CT development given by scientists in Table 1 have much in common. The selected fourth stage of generalization and evaluation of information corresponds to the phase of reflection of the technology of development of critical thinking.

Based on the analysis, we can identify the following stages of the development of critical thinking of future computer science teachers during classes (see Fig. 1. Stages of the development of critical thinking of future computer science teachers).

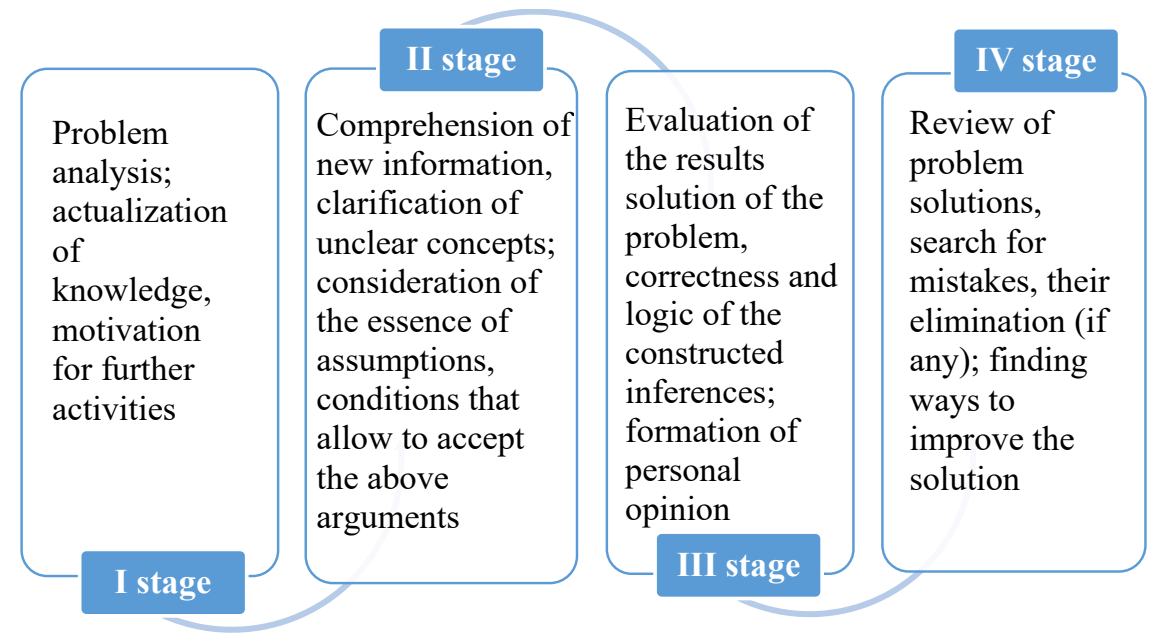

Fig. 1. Development stages of critical thinking of future IT teachers

According to CT researchers and media educators M. Solodokhina, S. Terno, D. Halpern, M. Shakirova, etc., among the most effective ways to develop critical thinking are solving problem, heuristic problems, using analysis of media texts, interactive methods: dialogue, discussion, brainstorming, case method, STEM cases, game technologies: role-playing, simulation games, etc. It should be emphasized that the problem, which provides internal motivation for educational activities, is a key condition for the development of CT, encourages independent acquisition of knowledge (Terno, 2014).

\section{Conclusions}

Thus, critical thinking is an integral part of the professional competencies of the future computer science teacher, an important component of modern higher education. 
Under the critical thinking of the future teacher of computer science, we understand the type of thinking and evaluation activities, which is manifested in special skills that are formed in the process of professional training, and which are necessary for the effective solution of professional problems.

Based on the theoretical analysis, the principles of development of critical thinking are outlined and four stages of development of critical thinking of future computer science teachers are singled out; It was found that the basis of critical thinking, which should be developed in the future specialist, are such qualities of mind as curiosity, flexibility, depth, discipline, organization of mental activity, critical thinking.

The usage of different methods and technologies for the development students' CT requires compliance with certain pedagogical conditions: taking into account age, level of academic achievement, existing life experience. A computer science teacher who has developed critical thinking will be able to master the necessary professional competencies, productively carry out pedagogical activities, self-improvement, reflect on their own pedagogical achievements and set new goals.

We see the prospects for future research in finding out the peculiarities of the development of critical thinking in future IT teachers in the process of professional training.

\section{References}

The Future of Jobs Report 2020. https://www.weforum.org/reports/the-future-of-jobs-report-2020 [in English]

Barbinova, A.V. (2018). Krytychne myslennja-zaporuka uspikhu pedaghoghichnoji dijaljnosti [Critical thinking is the key to the success of pedagogical activity]. Vytoky pedaghoghichnoji majsternosti, 22, 13-17. [in Ukrainian]

Bondar, V.I. (2014). Krytychne myslennja v konteksti vnutrishnjoji j zovnishnjoji svobody ljudyny [Critical thinking in the context of the internal and external freedom of the people]. Visnyk Instytutu rozvytku dytyny. Serija: Filosofija, pedaghoghika, psykhologhija, 36, 68-75. [in Ukrainian]

Vitvycjka, S.S. (2014). Rozvytok tvorchogho myslennja majbutnikh maghistriv osvity jak umova jikh tvorchoji samorealizaciji [Development of creative thinking of future masters of education as a condition of their creative self-realization]. Andraghoghichnyj visnyk: Naukove elektronne periodychne vydannja, 5, 88-96. http://eprints.zu.edu.ua/16985/1/\%D0\%B2\%D1\%96\%D1\%8 $2 \% \mathrm{D} 0 \% \mathrm{~B} 2 \% \mathrm{D} 0 \% \mathrm{~B} 8 \% \mathrm{D} 1 \% 86 \% \mathrm{D} 1 \% 8 \mathrm{C} \% \mathrm{D} 0 \% \mathrm{BA} \% \mathrm{D} 0 \% \mathrm{~B} 0 . \mathrm{pdf}$ [in Ukrainian]

Ghusak, P.M., Ghusak, L.Je. (2015). Kompetenciji i kompetentnosti u pidghotovci fakhivcja [Competences and competencies in specialist training]. Naukovi zapysky Vinnycjkogho derzhavnogho pedaghoghichnogho universytetu imeni Mykhajla Kocjubynsjkogho. Serija: Pedaghoghika i psykhologhija, 43, 7-10. [in Ukrainian]

Zhaldak, M.I. (1989). Systema podghotovky uchytelja k yspoljzovanyju ynformacyonnoj tekhnologhyy $v$ uchebnom processe [The system of teacher training for the use of information technology in the educational process] [Doktorstkaja dysretacyja]. Akademyja pedaghoghycheskykh nauk SSSR, NYY soderzhanyja y metodov obuchenyja. Moskva. [in Russian]

Zhaldak, M.I., Ramsjkyj, Ju.S. Rafaljsjka, M.V. (2009). Modelj systemy socialjno-profesijnykh kompetentnostej vchytelja informatyky [Model of the system of socio-professional competencies of a computer science teacher]. Naukovyj chasopys Nacionaljnogho pedaghoghichnogho universytetu imeni M.P. Draghomanova. Serija 2: Komp'juterno-orijentovani systemy navchannja, 7 (14), 3-10. [in Ukrainian] 
Zayr-Bek, S.Y., Mushtavynskaja, Y.V. (2011). Razvytye krytycheskogho mblshlenyja na uroke: posobye dlja uchytelej obshheobrazovateljnykh uchrezhdenyj [Developing critical thinking in the classroom: a guide for teachers of educational institutions] (2-e yzd.). Moskva: Prosveshhenye. [in Russian]

Zhukockaja, A.V., Chernenjkaja, S.V. (2019). Krytycheskoe myshlenye y egho rolj v formyrovanyy professyonaljnykh kompetencyj studentov pedaghoghycheskogho vuza [Critical thinking and its role in the formation of professional competencies of students of a pedagogical university]. Vestnyk MGhPU. Seryja: Fylosofskye nauky. Moskva, 4(32), 67-81. https://doi.org/10.25 688/2078-9238.2019.32.4.08 [in Russian]

Kokun, O.M. (2012). Psykhologhija profesijnogho stanovlennja suchasnogho fakhivcja [Psychology of professional development of a modern specialist] [Monoghrafija]. Kyjiv: DP "Informacijno-analitychne aghenstvo". [in Ukrainian]

Kukushkyna, Ju.A., Spyrydonov, V.F. (2008). Krytycheskoe myshlenye kak faktor professyonaljnoj kompetentnosty proghrammystov [Critical thinking as a factor in the professional competence of programmers]. Psykhologhyja. Zhurnal Vysshej shkoly ekonomyky, 5(1), 165-174. [in Russian]

Kuljutkyn, Ju.N., Bezdukhov, V.P. (2002). Cennostnye oryentyry y koghnytyvnye struktury v dejateljnosty uchytelja [Value orientations and cognitive structures in the teacher's activity]. Samara: SamGhPU. [in Russian]

Ludova, O.M. (2009). Modelj razvytyja krytycheskogho myshlenyja u budushhykh uchytelej ynformatyky $v$ processe obuchenyja dyscyplynam ynformatycheskogho cykla [A model for the development of critical thinking in future teachers of informatics in the process of teaching the disciplines of the informatics cycle]. Sybyrskyj pedaghoghycheskyj zhurnal, 10, 105-112. https://cyberleninka.ru/article/n/model-razvitiya-kriticheskogo-myshleniya-u-buduschih-uchiteley-informatiki-v-protsesse-obucheniya-distsiplinam-informagicheskogo [in Russian]

Morze, N.V., Kuzjminsjka, O.Gh., Vember, V.P., Barna O.V. (2010). Kompetentnisni zavdannja jak zasib formuvannja informatychnoji kompetentnosti v umovakh neperervnoji osvity [Competence tasks as a means of forming information competence in the conditions of continuing education]. Informacijni tekhnologhiji v osviti: Zbirnyk naukovykh pracj. Kherson: Vydavnyctvo $K h D U, 4,48-62$. [in Ukrainian]

Nacionaljna dopovidj pro stan i perspektyvy rozvytku osvity $v$ Ukrajini [National report on the state and prospects for the development of education in Ukraine] / Nacionaljna akademija pedaghoghichnykh nauk Ukrajiny. (2016). V.Gh. Kremenj (Red.). Kyjiv: Pedaghoghichna dumka. [in Ukrainian]

Raven, Dzh. (2002). Kompetentnostj v sovremennom obshhestve. Vyjavlenye, razvytye y realyzacyja [Competence in modern society. Identification, development and implementation]. Moskva. (Oryghynaljnaja rabota opublykovana 1984). [in Russian]

Selevko, Gh.K. (2006). Encyklopedyja obrazovateljnykh tekhnologhyj: Tom 1 [Encyclopedia of Educational Technologies: Vol 1]. V 2 tomah. Moskva: NYY shkoljnykh tekhnologhyj. [in Russian]

Sukhomlynsjkyj, V.O. (1976). Problemy vykhovannja vsebichno rozvynenoji osobystosti: Tom 1. [Problems of education of a comprehensively developed personality: Vol.1]. Vybrani tvory: 5 tomakh. Kyjiv: Radjansjka shkola. [in Ukrainian]

Paul, R.W. (1990). Krytycheskoe myshlenye: Chto neobkhodymo kazhdomu dlja vyzhyvanyja $v$ bystro menjajushhemsja myre [Critical thinking: What every person needs to survive in a rapidly changing world]. Rohnert Park, CA: Center for Critical Thinking and Moral Critique, Sonoma State Univ. https://evolkov.net/critic.think/Paul.R/index.html. [in Russian] 
Profesijnyj standart za profesijamy "Vchytelj pochatkovykh klasiv zakladu zaghaljnoji serednjoji osvity", "Vchytelj zakladu zaghaljnoji serednjoji osvity", "Vchytelj z pochatkovoji osvity" (z dyplomom molodshogho specialista" [Professional standard for the professions "Primary school teacher of general secondary education", "Teacher of general secondary education", "Primary education teacher (with a diploma of junior specialist)"]: zatv. Nakazom Ministerstva rozvytku ekonomiky, torghivli ta siljsjkogho ghospodarstva Ukrajiny vid 23.12.2020 r. № 2736 . https://www.me.gov.ua/Documents/Detail?lang=uk-UA\&id=22469103-4e36-4d41-b1bf-2883 38 b3c7fa\&title=RestrProfesiinikhStandartiv. [in Ukrainian]

Semenova, O.M. (2018) Soderzhanye ponjatyja «krytycheskoe myshlenye uchytelja» [The content of the concept of «critical thinking of a teacher»]. Povolzhskyj pedaghoghycheskyj vestnyk. Tom 6, 3(20), 70-76. [in Russian]

Terno, S.A. (2014). Obuchenye krytycheskomu myshlenyju - "ekzotycheskye pryemy" yly reshenye netryvyaljnykh problem? [Critical thinking training - "exotic techniques" or solving nontrivial problems?]. Ghumanytarnye nauchnye yssledovanyja, 1. https://human.snauka. ru/2014/01/5594 [in Russian]

Krouford, A, Vendy Saul, E, Metiuz, S, Makinster, D. (2006). Tekhnolohii rozvytku krytychnoho myslennia uchniv [Technologies for the development of critical thinking of pupils]. (O.I. Pometun, Red.). http://www.criticalthinking.expert/shop/tehnologiyi-rozvytku-krytychnogo-myslennya-uchniv/ [in Ukrainian]

Tjaghlo, O.V. (2017). Dosvid zasvojennja krytychnogho myslennja v ukrajinsjkij vyshhij shkoli [Experience of mastering critical thinking in Ukrainian higher school]. Filosofija osvity, 2 (21), 240-257. [in Ukrainian]

Tjaghlo, O.V. (2008). Krytychne myslennja: Navchaljnyj posibnyk [Critical Thinking: A Textbook]. Kharkiv: Vyd. ghrupa "Osnova": "Tryada +". [in Ukrainian]

Shakirova, M.D. (2006). Formyrovanye krytycheskogho myshlenyja uchashhykhsja y studentov: modelj y tekhnologhyja [Formation of critical thinking in pupils and students: model and technology]. Obrazovateljnye tekhnologhyy y obshhestvo, 9 (4), 284-292. [in Russian] 